\title{
Effects Of Camber Of Beam On Behavior Of Single Span Portal Frames
}

\author{
Kanaan Sliwo Youkhanna Athuraia \\ College of Engineering-University of Dohuk
}

\begin{abstract}
An attempt is made to study the effect of camber on the behavior (deflection and failure load) of single span portal frames under concentrated load. Two types of cambering were used, the first by cambering both top and bottom surfaces of the beam and the second by cambering the bottom surface only (the top surface is kept leveled) which is more acceptable from point of view of uniformity of super imposed dead load distribution.

There is a considerable effectiveness of the camber on the failure load compared with straight beams (without camber). Also, there is effectiveness considering (dead+live) load deflections for cambered beams compared with straight beams.
\end{abstract}

Keyword : Membrane Action, Camber, Concentrated Load, Deflection, Failure.

تأثثير تحدب الجسور على سلوك الهياكل احادية الفضاء

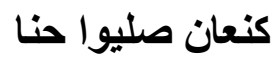




\section{كلية الهندسة - جامعة دهوك}

\section{الخلاصة}

تضمن البحث دراسة تأثثر تقوس العتبات (نحو الأسفل) على تصرف (الأنحر اف "الأوداء

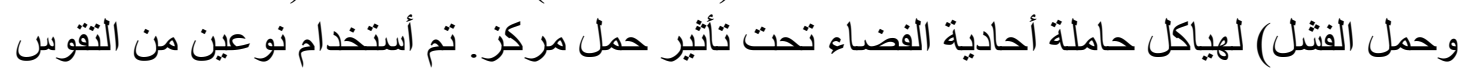

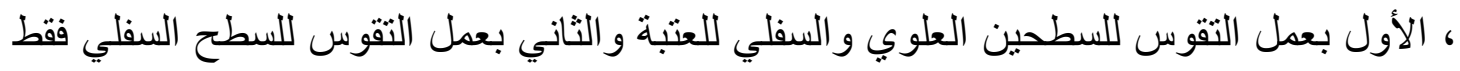

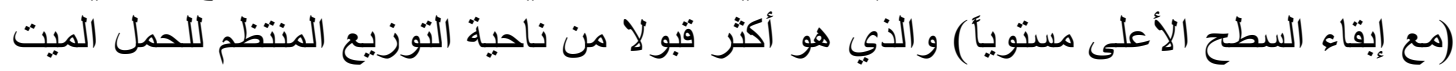

أظهرت النتائج تأثير واضح للتقوس على حمل الفثل بالمقارنة مع العتبة المستقيمة (بدون

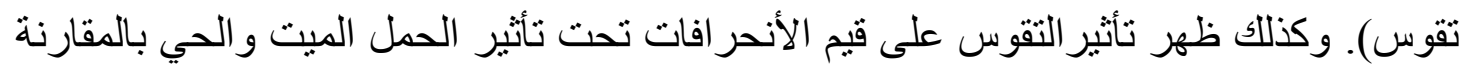

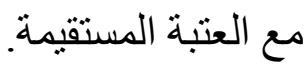

\section{Introduction}

Reinforced concrete is considered (due to its durability, relative low cost and relative high compressive strength) as one of the most important structural materials.

Restrained forces (at the ends of a member) may be mobilized if some camber (arching by shallow curvature) is introduced to flexural 
members (beams or slabs). This axial restraint acts in a similar manner as an axial pre-stressing force [1].

The maximum permissible deflection may be exceeded if camber is provided so that the total deflection minus camber do not exceed the permissible limit $[2,3]$.

Membrane action (axial restraining force) is activated due to actual restraint at the ends of the beams (straight or cambered) [4]. The influence of membrane action cannot be ignored [5]. Particular attention was paid to the contribution of compressive membrane action to the load carrying capacity [6].

\section{Scope Of Research}

An attempt is made to study the effect of camber on single span portal frames with beams (cambered at bottom surface and leveled at top surface).
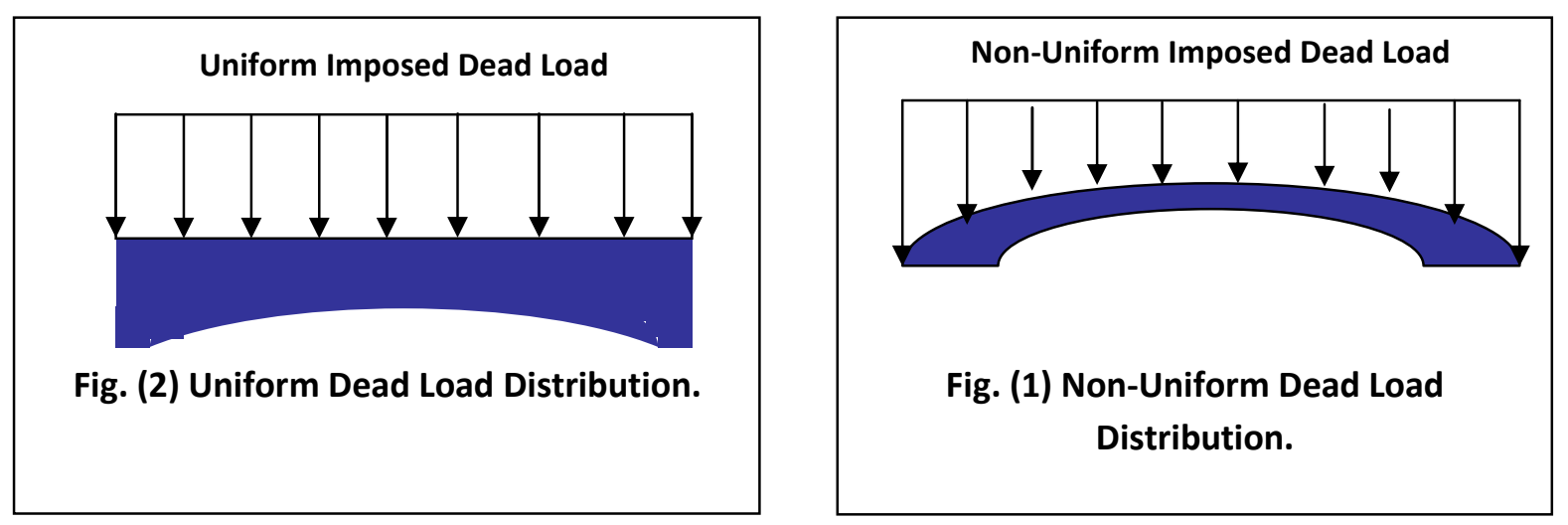
The previous researches $[1,4]$ dealt with beams that are cambered at top and bottom surfaces. This case of cambering will cause the imposed dead loads (tiles and the materials beneath tiles) to be applied in non uniform manner across the beam span, Fig. (1).

In this study, the cambered models investigated are more practical from point of view of uniform imposed dead load application and in reducing the amount of concrete used, Fig. (2).

The previous researches $[1,4]$ dealt with beams that are subjected to uniformly distributed loads, while in the present study, an attempt is made to investigate the effect of camber on the behavior of beam under the concentrated load.

Five models were cast, frame (F1) (with straight beam) as the basis of design and comparison, frame (F2) (with cambered beam where top and bottom surfaces are to be cambered) as the basis of comparison with frames (F3), (F4) and (F5) where the bottom surface of the beams is cambered only. The shape and frame configuration are given in Appendix (A) and the design details are given in Appendix (B).

\section{Computer Analysis}

Before the experimental work was conducted, a computer plastic analysis (using P-FRAME software) was performed to check (theoretically) the applicability and effectiveness of the suggested cambered models. Geometric details, material properties, node numbering, some of the results are given in APPENDIX (C).

\section{Deflection Calculation}

The five frames were subjected to dead load $\left(\mathrm{P}_{\mathrm{DL}}=5.60 \mathrm{kN}\right)$ for 30 days and the deflection readings were measured and are given in Table (1).

Table (1) Actual (measured) deflection due to dead loads

\begin{tabular}{|l|l|}
\hline & Deflection $(\mathrm{mm})$ \\
\hline
\end{tabular}




\begin{tabular}{|c|c|c|c|c|}
\hline Frame & $\begin{array}{c}(1) \\
\text { Day }^{+}\end{array}$ & $\begin{array}{c}(10) \\
\text { Days }\end{array}$ & $\begin{array}{c}\text { Days } \\
\text { Days }\end{array}$ & 0.599 \\
\hline F1 & 0.180 & 0.399 & 0.461 & 0.802 \\
\hline F2 & 0.196 & 0.514 & 0.681 & 0.830 \\
\hline F3 & 0.240 & 0.546 & 0.709 & 0.821 \\
\hline F4 & 0.222 & 0.531 & 0.700 & 0.816 \\
\hline F5 & 0.203 & 0.521 & 0.687 & $\begin{array}{c}\text { of imposed } \\
\text { dead loads. }\end{array}$ \\
\hline${ }^{+}$Measured from the time of application
\end{tabular}

It can be seen that the deflections of the cambered frames are greater than those of the straight frame. This is may be because the membrane forces have not been activated yet, and this is due to the small deflection occurs. It can also be seen that frame (F5) is the best frame among (F3, F4 \& F5) compared with frame (F2). Fig (3) shows the relation between deflections due to dead loads only with time in days
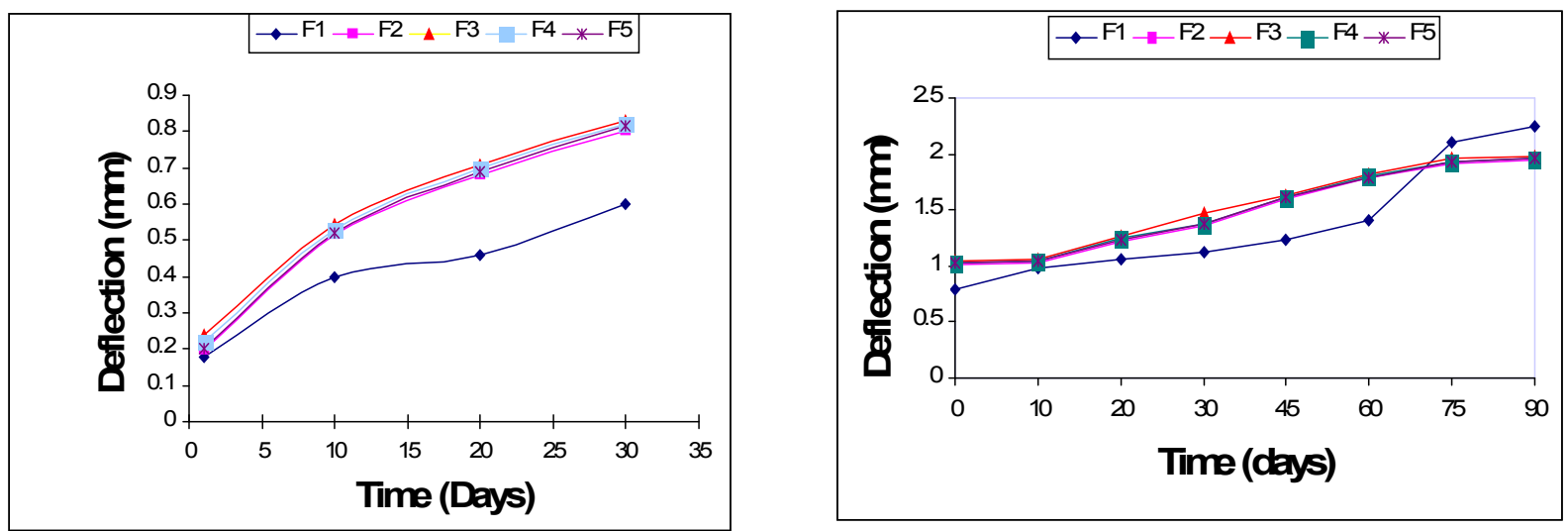

Fig.(3) Deflection-Time relation under Time relation imposed dead loads only \& live loads.
Fig. (4) Deflectiondead

Fig (4) shows the relation between deflection due to dead and live loads with time in days. 
After 30 days of the application of imposed dead loads, another load $\left(\mathrm{P}_{\mathrm{LL}}=6.574 \mathrm{kN}\right)$ was applied as live load and the deflection readings were measured and are given in Table (2).

Table (2) Actual (measured red) deflection due to dead and live loads

\begin{tabular}{|c|c|c|c|c|c|c|c|c|}
\hline \multirow{2}{*}{} & \multicolumn{7}{|c|}{ Deflection (mm) } \\
\cline { 2 - 9 } & $\begin{array}{c}1 \\
\text { day }^{+}\end{array}$ & $\begin{array}{c}10 \\
\text { day }\end{array}$ & $\begin{array}{c}20 \\
\text { day }\end{array}$ & $\begin{array}{c}30 \\
\text { day }\end{array}$ & $\begin{array}{c}45 \\
\text { day }\end{array}$ & $\begin{array}{c}60 \\
\text { day }\end{array}$ & $\begin{array}{c}75 \\
\text { day }\end{array}$ & $\begin{array}{c}90 \\
\text { day }\end{array}$ \\
\hline Frame & 0.788 & 0.979 & 1.067 & 1.116 & 1.239 & 1.411 & 2.109 & 2.247 \\
\hline F2 & 1.015 & 1.028 & 1.217 & 1.366 & 1.600 & 1.788 & 1.916 & 1.952 \\
\hline F3 & 1.046 & 1.059 & 1.258 & 1.474 & 1.625 & 1.812 & 1.955 & 1.982 \\
\hline F4 & 1.036 & 1.045 & 1.243 & 1.382 & 1.619 & 1.802 & 1.938 & 1.969 \\
\hline F5 & 1.024 & 1.037 & 1.230 & 1.373 & 1.608 & 1.793 & 1.925 & 1.959 \\
\hline${ }^{+}$Measured from the time of application of live loads. \\
\hline
\end{tabular}

It can be seen that up to 70 days [from the application of live load], the total deflection of cambered frames is still greater than that of the straight frame. After 70 days, there is a change in behavior, where the total deflection of cambered frames is now less than that of straight frame. It seems that the membrane action (restraint force) is being mobilized (after 70 days) in such a manner to act as a pre-stressing force increasing the compressive strength of the cambered frames, while in straight frames there was no such increasing in compressive strength.

\section{Failure Loads}

After 90 days from application of live loads, all the frames (F1, F2, F3, F4 \& F5) were subjected to load increment (which was applied for all frames at the same time) until failure. The actual failure loads are given in Table (3) and are shown in chart diagram shown in Fig.(5). 
Table (3) Failure loads

\begin{tabular}{|c|c|c|c|c|c|}
\hline Frame & F1 & F2 & F3 & F4 & F5 \\
\hline $\begin{array}{c}\text { Failure Load } \\
(\mathrm{kN})\end{array}$ & 16.001 & 17.250 & 16.675 & 16.970 & 17.110 \\
\hline
\end{tabular}

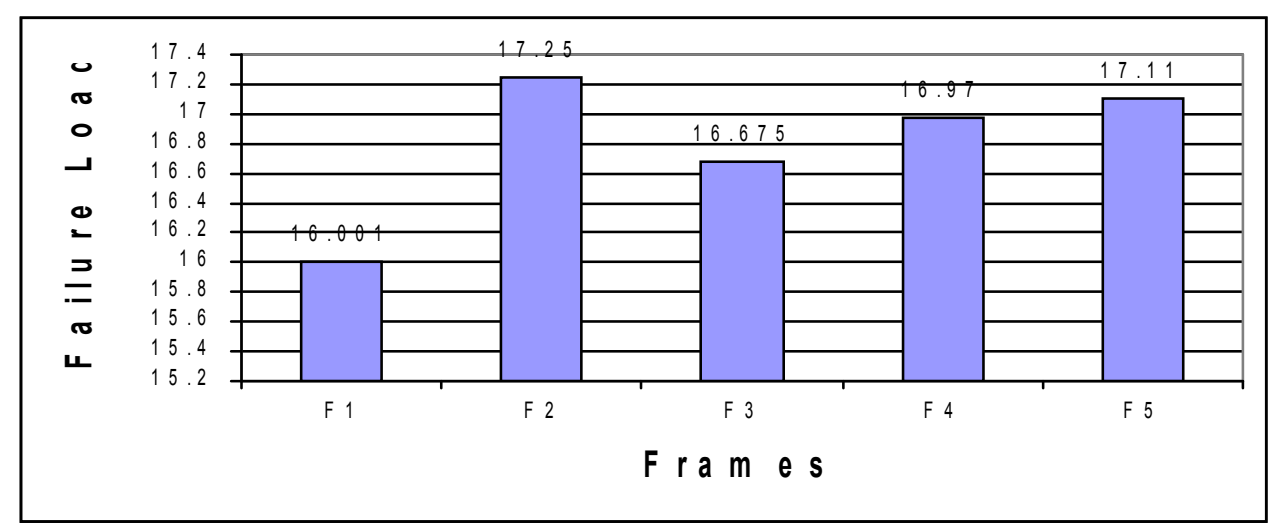

Fig. (5) Failure loads of all frames.

It can be seen that cambered frame (F2) is the best frame among all frames and this is expected due to the effect of the membrane action in increasing the load carrying capacity $[1,4]$ and because there is no change (reduction) in beam section.. Another point to be noticed is that all of the cambered frames are better than straight frame in load carrying (up to failure). Again (F5) is the best frame that gives results approaching those of frame (F2).

Table (4) gives the effectiveness (considering failure load) of each of the cambered frames (F3, F4 \& F5) compared to frames (F1, F2).

Table (4) Effectiveness (due to failure load)

\begin{tabular}{|r|c|c|c|c|c|}
\hline Frame & F1 & F2 & F3 & F4 & F5 \\
\hline Failure Load (kN) & 16.001 & 17.250 & 16.675 & 16.970 & 17.110 \\
\hline \multicolumn{6}{|c|}{ Effectiveness (Considering failure load) } \\
\hline
\end{tabular}




\begin{tabular}{|l|c|c|c|c|c|}
\hline $\begin{array}{l}\text { Comparing with } \\
\text { (F1) }\end{array}$ & 1.00 & 1.08 & $1.04^{+}$ & 1.06 & 1.07 \\
\hline $\begin{array}{l}\text { Comparing with } \\
\text { (F2) }\end{array}$ & $0.93^{++}$ & 1.00 & 0.97 & 0.98 & 0.99 \\
\hline
\end{tabular}

\footnotetext{
${ }^{+}$Effectiveness $=(16.675 / 16.001)=1.04$

${ }^{++}$Effectiveness $=(16.001 / 17.250)=0.93$
}

The application of the loads (Dead, Live and Failure) on the models were performed actually using concrete blocks, bricks, sags of gravel.

Computer plastic analysis (P-FRAME) is performed by applying (on each frame) the actual failure load. Some of the results are given in Table (5).

Table (5) Computer plastic analysis (P-FRAME) for failure load

\begin{tabular}{|c|c|c|c|c|}
\hline Frame & $\begin{array}{c}\text { Failure } \\
\text { Load }(\mathrm{kN})\end{array}$ & $\begin{array}{l}\Delta \mathrm{V} 12 \\
(\mathrm{~mm})\end{array}$ & $\begin{array}{l}\text { Load } \\
\text { Factor }\end{array}$ & $\begin{array}{c}\text { Joints of } \\
\text { Plastic Hinge }\end{array}$ \\
\hline \multirow{3}{*}{$\mathrm{F} 1$} & \multirow{3}{*}{$\mathrm{P}=16.001$} & 1.290 & 0.6098 & 12 \\
\hline & & 2.724 & 0.7608 & 22 \\
\hline & & 2.724 & 0.7608 & 2 \\
\hline \multirow{4}{*}{ F2 } & \multirow{4}{*}{$\mathrm{P}=17.250$} & 1.342 & 0.5517 & 12 \\
\hline & & 3.060 & 0.7607 & 22 \\
\hline & & 4.088 & 0.7313 & 2 \\
\hline & & 37.713 & 0.7387 & 23 \\
\hline \multirow{4}{*}{ F5 } & \multirow{4}{*}{$\mathrm{P}=17.110$} & 1.630 & 0.3235 & 12 \\
\hline & & 4.308 & 0.5253 & 22 \\
\hline & & 4.308 & 0.5253 & 2 \\
\hline & & 47.903 & 0.5331 & 23 \\
\hline
\end{tabular}


It can be seen that the frame (F1) which is straight needs three plastic hinges to reach failure while frames (F2 \& F5) that are cambered need four plastic hinges to reach failure. This was noticed experimentally, where the straight frame (F1) collapsed first then, after some load increments, the cambered frames (F2, F3, F4 \& F5) collapsed each in its turn. This is because the straight frame (F1) after three plastic hinges will transform into unstable beam condition (horizontal beam with three hinges on straight line) ${ }^{(7)}$ while the cambered frames (F2 \& F5) after three plastic hinges will transform into three hinged arch which is stable.

\section{Conclusions}

1- Cambered beams (frames) are better than straight ones under concentrated load (considering long time dead + live deflection and failure load).

2- Cambered beams with top surface being leveled are more practical (from the point of view of uniform super imposed dead load distribution) than cambered beams with top and bottom surfaces being cambered.

3- Cambered beams with top and bottom surfaces being cambered is the best beams considering long time dead + live deflection and failure load.

\section{References}

1- Essa, Mahdi Saleh, "Behavior of Concrete End-Restrained Shallow Curved Flexural Members", Ph. D. thesis, University of Baghdad, College of Engineering, 1997.

2- Building Code Requirements for Structural Concrete and Commentary-ACI 318M 05.

3- "IRAQI Building Code Requirements for Reinforced Concrete", Code 1, Building Research Center, Scientific Research Council, 1987.

4- Athuraia, Kanaan Sliwo, "Effect of Membrane Action on Results of Load Test", Ph. D. thesis, University of Baghdad, College of Engineering, 2004.

5- Huang ZH., Burgess IW., Plank RJ., "Non-linear Structural Modeling of a Fire Test Subject to High Restraint", Fire Safety Journal, 36(8):, 2001 Nov., 795-814. 
6- Peel-Cross J., Rankin GIB., Gilbert SG., Long AE., "Compressive Membrane Action in Composite Floor Slabs in the Cardington LBTF", Proceedings of the institution of Civil EngineersStructures \& Buildings, 146(2), May 2001, 217-226.

7- HSIEH, Yuan-Yu, "Elementary Theory of Structures", 2nd Ed., Prentice-Hall International Series, New Jersey, 1982.

8- Winter, George, Nilson, Arthur H., "Design Of Concrete Structures", $9^{\text {th }}$ Ed., McGraw-Hill Book Company, 1979.

APPENDIX (A)
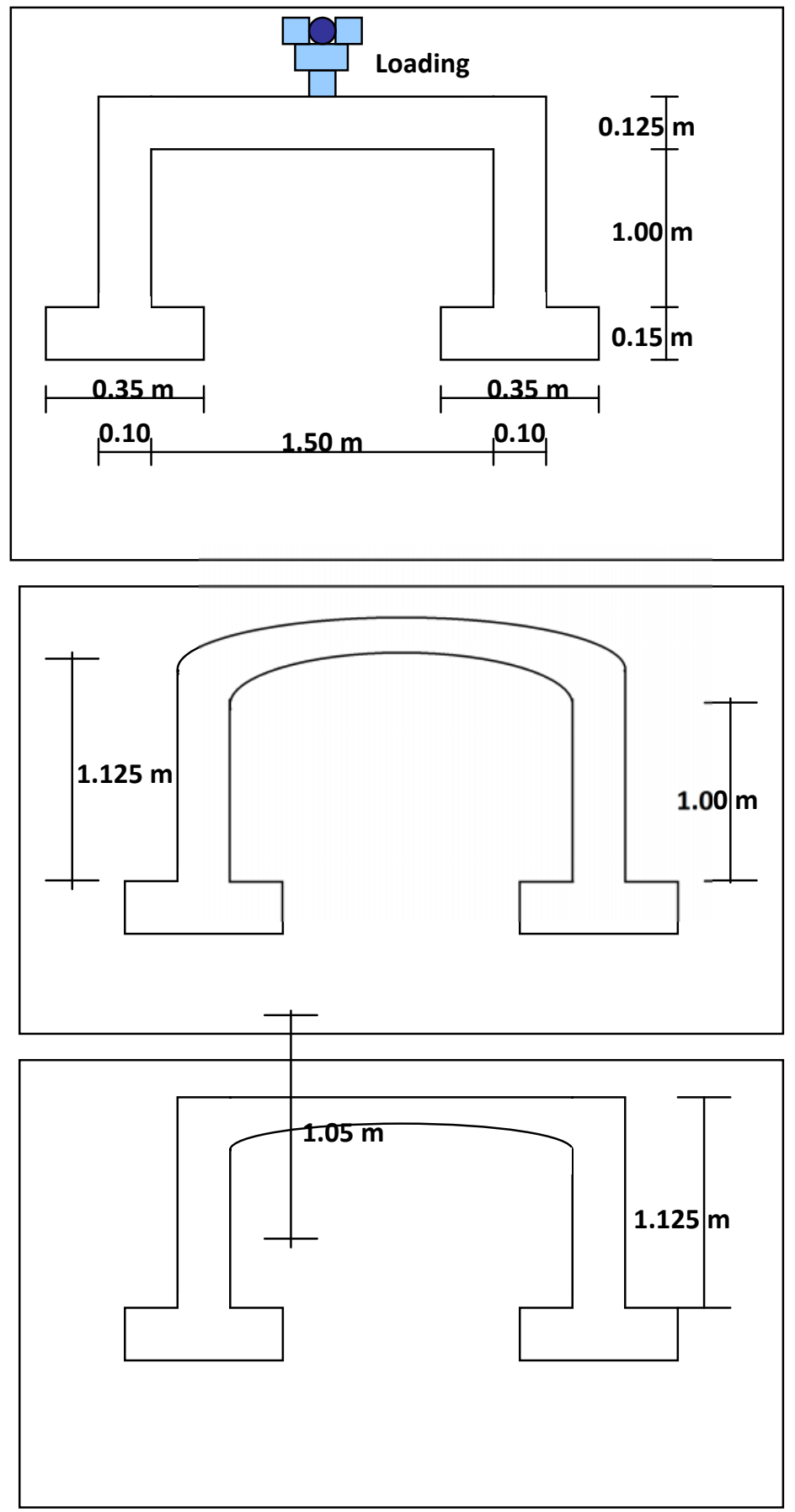


\section{APPENDIX (B)}

The actual dimensions of the members (preliminary analysis \& design) were as follows:

1- Beam: $(300 \times 500) \mathrm{mm} \&$ Span $=6.0 \mathrm{~m}$.

2- Column: $(300 \times 400) \mathrm{mm} \&$ Height $=4.0 \mathrm{~m}$.

3- Footing: $(1.4 \times 1.4 \times 0.45) \mathrm{m}$

The dimensions of the members for the models of the present study were chosen to be (1/4) scale of that of the actual frames. Hence, the dimensions for frames F1 \& F2 (the basis for comparison) are:

4- Beam: $(75 \times 125) \mathrm{mm} \&$ Span $=1.5 \mathrm{~m}$.

5- Column: $(75 \times 100) \mathrm{mm} \&$ Height $=1.0 \mathrm{~m}$.

6- Footing: $(0.35 \times 0.35 \times 0.125) \mathrm{m}$

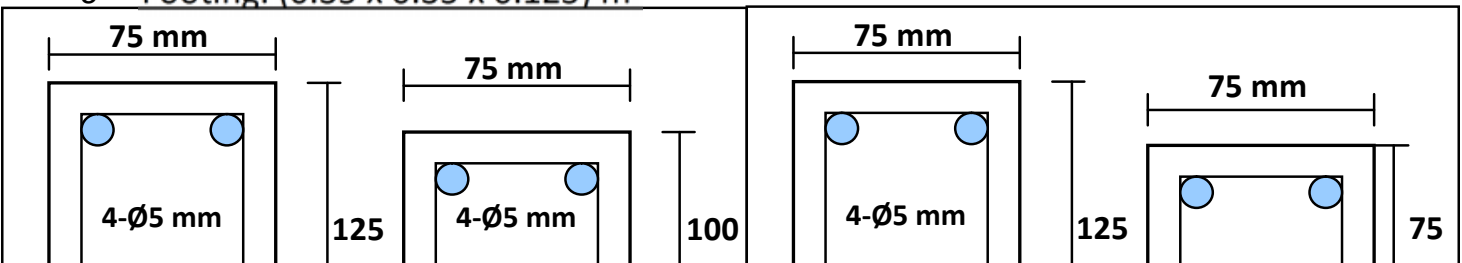




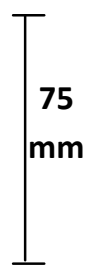




\section{APPENDIX (C)}

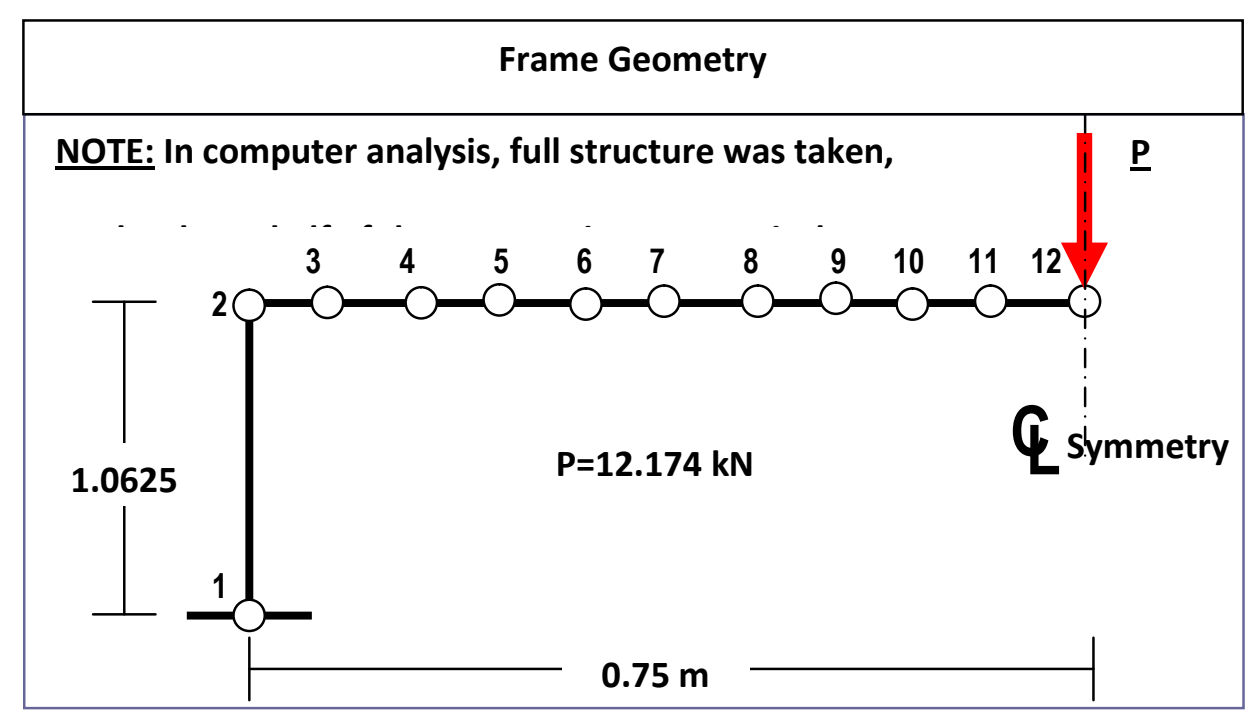

\section{Computer plastic analysis (P-FRAME)}

\begin{tabular}{|c|c|c|c|c|c|}
\hline \multirow[b]{2}{*}{ Frame } & \multirow[b]{2}{*}{$\begin{array}{l}\Delta \mathrm{V} 12 \\
(\mathrm{~mm})\end{array}$} & \multirow[b]{2}{*}{$\begin{array}{l}\text { Load } \\
\text { Factor }\end{array}$} & \multirow{2}{*}{$\begin{array}{c}\text { Joints of } \\
\text { Plastic } \\
\text { Hinge }\end{array}$} & \multicolumn{2}{|c|}{ Beam Axial Force at: $\quad(\mathrm{kN})$} \\
\hline & & & & $\mathrm{Member}^{+}$ & Member $^{++}$ \\
\hline \multirow{3}{*}{$\mathrm{F} 1$} & 1.442 & 0.719 & 12 & 1.411 & 1.411 \\
\hline & 4.421 & 1.000 & 22 & 3.218 & 3.218 \\
\hline & 4.421 & 1.000 & 2 & 3.218 & 3.218 \\
\hline \multirow{4}{*}{ F2 } & 1.345 & 0.782 & 12 & 2.270 & 1.699 \\
\hline & 3.062 & 1.001 & 22 & 3.750 & 3.033 \\
\hline & 4.097 & 1.036 & 2 & 4.098 & 3.332 \\
\hline & 37.717 & 1.047 & 23 & 5.063 & 4.297 \\
\hline \multirow{4}{*}{ F5 } & 1.634 & 0.455 & 12 & 1.929 & 1.594 \\
\hline & 6.477 & 0.967 & 4 & 5.535 & 4.834 \\
\hline & 6.477 & 0.967 & 20 & 5.535 & 4.834 \\
\hline & 89.061 & 0.980 & 1 & 7.017 & 6.317 \\
\hline
\end{tabular}

+ At the beginning of the beam.

${ }^{++}$At mid-span of the beam.

[ $\mathbf{M}_{\mathbf{p}}$ Calculation for frame (F1)]

Beam: $M_{p}=2.2826 \mathrm{kN} \cdot \mathrm{m}$

Column: $\mathrm{M}_{\mathrm{p}}=3.3131 \mathrm{kN} \cdot \mathrm{m}$ 
